Jurnal DISASTRI (Pendidikan Bahasa dan Sastra Indonesia)

Volume 3, Nomor 2, Agustus 2021| P-ISSN : 2716-4114 | E-ISSN: 2722-3329

\title{
ILOCUTION SPEAKING IN LANGUAGE INTERACTION OF SANTRI AT PONDOK PESANTREN NURUL ILMI WAL FIKRI JOMBANG
}

\author{
Abdur Rahman Haidar1, Udjang Pairin M.Basir ${ }^{2}$ \\ ${ }^{1,2}$ Prodi Pendidikan Bahasa dan Sastra Indonesia, Fakultas Ilmu Pendidikan, Universitas Hasyim Asy'ari
}

Corresponding Author: ${ }^{1}$ Rahmanhaidar0117@gmail.com

\begin{abstract}
When the students interact, there is what is called a speech act or language interaction which includes speakers and opposing speakers, both individually and in groups. When interacting, there will be the application of language acts responsively to their fellow scopes, as well as actions in the form of verbal and behavioral. A speaker performs speech acts well because they are used to their environment. As in the santri at the Nurul Ilmi Wal Fikri Jombang Islamic boarding school, for survival in the pesantren the santri interact and there must be a purpose and application or purpose of the interaction. In the application of communication, the researchers observed the students with the illocutionary phenomenon. There are three illocutions contained in this study, namely; directive illocutionary, expressive illocutionary, and commissive illocutionary. This study uses a descriptive qualitative method, with data collection techniques in the form of observation, note taking, and documentation. Data validity techniques include; data transcription, understanding data, verifying data, modifying data and analyzing data. The results of this study are the students at the Nurul Ilmi wal fikri Jombang Islamic boarding school when interacting there will definitely be an application and purpose in communication, which can be verbal or behavioral.
\end{abstract}

Keywords: Directive Illocutionary, Expressive Illocutionary, and Commissive Illocutionary

\section{TUTURAN ILOKUSI DALAM INTERAKSI BAHASA PARA SANTRI DI PONDOK PESANTREN NURUL ILMI WAL FIKRI JOMBANG}

\begin{abstract}
Abstrak
Ketika para santri berinteraksi di situlah terjadi yang namanya tindak tutur atau interaksi bahasa yang meliputi penutur dan lawan penutur baik secara individu maupun kelompok. Ketika berinteraksi akan timbul penerapan tindak berbahasa secara responsif pada sesama ruang lingkupnya, serta adanya tindakan berupa lisan maupun tingkah laku. Seorang penutur melakukan tindak tutur dengan baik karena sudah terbiasa terhadap lingkungannya. Seperti pada santri di pondok pesantren Nurul Ilmi Wal Fikri Jombang, untuk keberlangsungan hidup di pesantren para santri melakukan interaksi dan pasti ada tujuan dan penerapan atau maksud dari interaksi tersebut. Pada penerapan komunikasi itu maka peneliti mengamati para santri dengan fenomena ilokusi. Ilokusi yang terdapat pada penelitian ini ada tiga bagian yakni; ilokusi direktif, ilokusi ekspresif, dan ilokusi komisif. Penelitian ini menggunakan metode kualitatif deskriptif, dengan teknik pengumpulan data berupa observasi, simak catat, dan dokumentasi. Teknik keabsahan data berupa; transkrip data, memahami data, verifikasi data, memodifikasi data dan analisis data. Hasil dari penelitian ini adalah para santri di pondok pesantren Nurul Ilmi wal fikri Jombang pada saat berinteraksi pasti akan adanya suatu penerapan dan tujuan pada komunikasi bisa berupa lisan maupun tingkah laku.
\end{abstract}

Kata Kunci: Ilokusi Direktif, Ilokusi Ekspresif, dan Ilokusi Komisif

\section{PENDAHULUAN}

Pondok pesantren merupakan lembaga pendidikan tertua yang ada di Indonesia dan mengadopsi sistem pendidikan keagamaan yang berkembang sejak awal kedatangan Islam di Nusantara. Pondok berasal dari bahasa Arab dari kata funduuq yang bermakna penginapan atau asrama. Sedangkan arti pesantren dari kata pe-santri-an yang berarti tempat tinggal 
santri atau yang dikenal sebagai murid. Pesantren merupakan wadah atau media pendidikan modern untuk masyarakat pelosok pedesaan yang belum tersentuh dunia pendidikan (Alim,2010). Pondok pesantren merupakan tempat menimba, mengajar, dan mengamalkan ilmu di mana terbentuknya pesantren karena adanya seorang guru atau dikenal sebagai kyai dan menetapnya seorang murid/santri untuk menimba ilmu dari sang kyai.

Pengertian santri secara umum merupakan orang yang belajar agama Islam dan mendalami agama Islam di pesantren yang menjadi tempat belajar bagi para santri. Asal usul kata santri menurut (Rizki 2012:34) setidaknya ada 2 pendapat yang dapat dijadikan rujukan. Pertama, santri berasal dari bahasa Jawa dari kata Cantrik yang berarti seseorang yang mengikuti seorang guru kemanapun pergi atau menetap dengan tujuan menimba ilmu kepadanya. Kedua, santri berasal dari bahasa Sansekerta yang bermakna melek huruf. Santri dibagi dua kelompok jika dirunut dari tradisi pesantren, yakni pertama santri mukim merupakan santri yang berasal dari daerah jauh dan menetap di pondok pesantren untuk menimba ilmu serta mengurus kegiatan di pondok pesantren. Kedua, santri kalong merupakan santri yang berasal dari penduduk sekitar yang dekat dengan pesantren hanya saja tidak tinggal di pesantren melainkan di rumah, waktu di pesantren hanya untuk belajar dan mengaji.

Santri selain menimba ilmu pendidikan dan keagaaman, santri juga diajarkan memiliki rasa sosial yang tinggi karena santri juga makhluk sosial yang saling membutuhkan satu sama lain. Supaya saling menjaga hubungan sosial maka perlu adanya interaksi dengan alat komunikasi yang dikenal dengan bahasa. Bahasa dengan masyarakat sangat erat hubungannya seperti ikan dan air, saling keterkaitan dan membutuhkan satu sama lain. Masyarakat membutuhkan bahasa untuk berkomunikasi sesamanya hingga menjadi hubungan sosial. Selain menjadi alat komunikasi bahasa bisa digunakan sebagai alat pengikat dan pengatur masyarakat, seperti mereka yang merasa memiliki dan menggunakan bahasa yang sama disebut masyarakat bahasa dilakukannya baik secara individu maupun berkelompok (Muhammad, 2017: 38)

Ketika para santri berinteraksi di situlah terjadi yang namanya tindak tutur atau interaksi bahasa yang meliputi penutur dan lawan penutur baik secara individu maupun kelompok. Ketika berinteraksi akan timbul penerapan tindak berbahasa secara responsif pada sesama ruang lingkupnya, serta adanya tindakan berupa lisan maupun tingkah laku. Seorang penutur melakukan tindak tutur dengan baik karena sudah terbiasa terhadap lingkungannya, itu terjadi karena adanya sosiopragmatik. Sosiopragmatik dapat diartikan keadaankeadaan lingkungan setempat mengenai tindak tutur kebahasaan (Tarigan, 1986: 6).

Sosiopragmatik merupakan keadaan atau kondisi lingkungan yang menjadi prinsip kerjasama dan kesopanan yang secara langsung dan dapat berubah-ubah dalam kebudayaan masyarakat, yang mampu memengaruhi gaya bahasamya (Tarigan, 2001:26). Sosiopragmatik ilmu yang tidak dapat berdiri sendiri dengan kata lain menyangkut beberapa ilmu seperti sosiolinguistik dan pragmatik. Sosiopragmatik merupakan bagian dari pragmatik, sehingga pragmatik menjadi dasar sosiopragmatik (Revita, 2017:03). Sosiopragmatik sendiri merupakan kata lain pragmatik yang membahas dari sudut pandang lingkungan sosial yang mendukung bahasa tersebut (Leech, 1983:10-11).

Tindak berbahasa bisa disebut sebagai pragmatik, pragmatik menurut (Purwo, 1990:15) merupakan meneliti hubungan diantara lambang dan penafsiran. Maksud dari lambang dan penafsiran tersebut menjelaskan tentang satuan ujaran, berupa satu kalimat atau lebih yang "membawa" makna tertentu, di dalam pragmatik ditentukan atas hasil penafsiran lawan penutur/pendengar. Contohnya, pada sore hari seorang ketua pondok berbicara kepada pengurus kebersihan dengan tuturan, "Bayooo rek, pondok e bersih pol e" kemudian pengurus kebersihan merespon "Nggih mas, sabar nunggu anak-anak dulu, lagian belom jam 4, nanti ya tak kasih pengumuman untuk ro;an bersama". 
Pengurus kebersihan merespon tuturan seperti itu karena sudah paham apa yang dimaksud dari percakapan ketua pondok, dan menurutnya apa yang dikatakan ketua pondok untuk bersegera melakukan kegiatan ro'an bersama. Ro;an di artikan sebagai bersih-bersih atau kerja bakti, julukan bahasa bagi pondok pesantren.

Kedudukan bahasa dalam masyarakat menempatkan manusia sebagai makhluk sosial yang mengakibatkan setiap tuturan manusia akan dipengaruhi oleh keadaan dan situasi. Faktor-faktor luar bahasa yang memengaruhi tuturan, antaralain: tempat dan suasana tuturan, peristiwa tuturan, intonasi tuturan, alat tuturan dan jenis kelamin penutur atau mitra tutur (Wijana, 2013:7-9)

Pragmatik bisa dikatakan ilmu yang mempelajari tentang tindak tutur, karena bisa memengaruhi kondisi dan situasi pada saat berinteraksi antara penutur dengan lawan penutur. Pragmatik juga memiliki cabang teori tentang tindak tutur seperti teori ilokusi. Ilokusi merupakan tuturan yang dilakukan oleh penutur untuk memberitahu informasi beserta memengaruhi lawan penutur untuk bertindak melakukan sesuatu (Rusminto, 2015:67). Sedangkan menurut (Yuliana, 2013: 4) Ilokusi adalah tindak tutur untuk melakukan sesuatu atau informasi dengan manfaat dan tujuan khusus.

Ilokusi dijabarkan menjadi lima bagian yakni; Asertif adalah tuturan apa adanya tentang kebenaran dari percakapan sang penutur. Direktif merupakan tuturan yang dapat atau diharapkan bisa memengaruhi lawan tutur untuk melakukan sesuatu. Ekspresif merupakan tuturan yang dapat atau diharapkan agar memberikan hal yang perbaikan kepada lawan penutur. Komisif merupakan percakapan yang mengikat penutur untuk melakukan sesuatu di masa yang akan datang. Deklarasi merupakan tuturan yang dilakukan penutur untuk menjadikan keadaan dengan suasana yang baru. Mengacu pada pendapatpendapat di atas adanya interaksi supaya ada penerapan tindak lanjut dari komunikasi tersebut bisa berupa ucapan maupun tindakan. Salah satunya pada para santri di pondok pesantren Nurul Ilmi Wal Fikri Jombang, untuk keberlangsungan hidup di pesantren para santri melakukan interaksi dan pasti ada tujuan dan penerapan atau maksud dari interaksi tersebut. Pada penerapan komunikasi itu maka peneliti mengamati para santri dengan memakai teori ilokusi.

Dari komunikasi para santri dan warga pondok pesantren Nurul Ilmi Wal Fikri Jombang. Maka peneliti hanya meneliti penerapan interaksi bahasanya. Penerapan Interaksi bahasa tersebut memakai teori ilokusi pada penelitian ini, mencakup tiga bagian yakni Direktif, Ekspresif, dan Komisif. Sehingga bila tujuan pada penelitian ini adalah untuk mengetahui Ilokusi direktif, ilokusi ekspresif dan ilokusi komisif yang dipakai warga pesantren atau para santri ketika berinteraksi. Adapun fokus penerapan komunikasi yang menjadi pembahasan dalam penelitian ini adalah penerapan komunikasi yang berjudul Tuturan Ilokusi dalam interaksi bahasa para santri di Pondok Pesantren Nurul Ilmi Wal Fikri Jombang.

\section{METODE PENELITIAN}

Desain penelitian yang digunakan pada penelitian ini adalah penelitian Kualitatif. Sementara jenis penelitian pada penelitian ini adalah penelitian deskriptif, yakni penelitian yang berusaha untuk mendiskripsikan aspek penerapan tindak berbahasa para santri di pondok pesantren Nurul Ilmi Wal Fikri Jombang. Adapun sumber data penelitian ini adalah kata dan kalimat yang digunakan berinteraksi para santri seperti aksi tindak berbahasa dalam tujuan dan penerapan dalam berkomunikasi yang dilakukan oleh para santri pondok pesantren Nurul Ilmi Wal Fikri. Data penelitian ini adalah penerapan dan tujuan yang dikembangkan dalam berkomunikasi para santri dengan teori ilokusi.

Teknik pengumpulan data yang digunakan pada penelitian ini adalah observasi, simak catat, dan dokumentasi. Observasi dilakukan dengan tujuan untuk mendapatkan data secara langsung dari objek yang diteliti yakni interaksi bahasa para santri, dengan cara mengamati dan 
merekam tindak berbahasa para santri di lingkup pesantren. Simak catat dilakukan dua proses, pertama peneliti melakukan transkripsi data-data yang dianalisis dari hasil rekaman pada saat observasi. Kedua, peneliti mencatat hasil transkripsi yang mengandung jenis penerapan dan tujuan yang dikembangkan dalam komunikasi yang dilakukan para santri dengan menggunakan teori Ilokusi. Dokumentasi digunakan untuk membuktikan penelitian karena dokumen merupakan sumber yang stabil, dapat berguna sebagai bukti untuk pengujian dan mempunyai sifat alamiah.

Cara yang dilakukan peneliti untuk menguji keabsahan data pada penelitian ini adalah dimulai dengan tahap transkipsi data berupa tuturan para santri dari bahasa lisan ke bahasa tulisan. Selanjutnya tahap membaca atau memahami data dengan cara memilah-milah data sesuai kriteria atau fokus penelitian. Setelah itu data akan di verifikasi, selanjutnya akan diberi kode sesuai fokus penelitian. Terakhir tahap penganalisisan peneliti mengecek data dan meminta bantuan kepada pihak lain (dosen pembimbing atau teman sejawat).

\section{PEMBAHASAN}

Berdasarkan hasil penelitian mengenai tuturan ilokusi dalam interaksi bahasa para santri di pondok pesantren Nurul Ilmi Wal Fikri Jombang dimaksudkan dalam fenomena ilokusi. Fungsi dari interaksi ilokusi sebagai memengaruhi dan memberi informasi kepada lawan tutur untuk melakukan sesuatu. Pengaruh dari ilokusi tidak hanya melakukan apa yang dikatakan penutur saja melainkan bisa sebagai evaluasi (kritik) dan menciptakan hal baru (memberi maaf).

Interkasi bahasa para santri dan warga pondok pesantren yang meliputi ustadz, pengurus dan kyai dilakukan di pondok pesantren Nurul Ilmi Wal Fikri Jombang dengan tempat yang berbeda serta tidak jauh dari ruang lingkup pondok pesantren. Peristiwa tersebut dilakukan agar tercapainya data yang dibutuhkan dalam penelitian. Fenomena ilokusi pada penelitian ini ditemukan tiga jenis yakni; ilokusi direktif, ilokusi eksoresif, dan ilokusi komisif. Ketika berkomunikasi beberapa tuturan dapat dikembangkan dengan adanya tujuan maksud tertentu tergantung menyesuaikan kondisi dan situasi. Mengenai hasil penelitian pada fenomena ilokusi pada tujuan interaksi para santri itu dapat diuraikan sebagai berikut.

\section{Ilokusi Direktif}

Tindak berbahasa para santri di pondok pesantren Nurul Ilmi Wal Fikri Jombang ini menyimpan fenomena ilokusi direktif. Terjadinya fenomena ilokusi direktif ini terjadi di beberapa tempat seperti di aula pengajian dan kantor pengurus. Hal tersebut dilaksanakan supaya terwujudnya data yang dibutuhkan dalam penelitian. Tindak berbahasa para warga pondok pesantren memiliki tujuan dan maksud dalam berinteraksi dapat dikembangkan dalam berupa tindakan maupun balasan interaksi.

Seperti pada saat waktu pembelajaran berlangsung ketika ustadz memberi isyarat kepada santrinya bahwa papan tulis itu kotor supaya dibersihkan. Sebagaimana interaksi bahasa ustadz dengan santri sebagai berikut.

Kutipan (1) kode IBA3SDU

U : "He'e yowes betul, sekarang saya jelaskan secara singkat saja ya... duh papane ruesike"

(ya sudah betul, sekarang saya jelaskan secara singkat saja ya.. duh papanya bersih ya)

(konteks: menyindir para santri untuk membersihkan papan tulisnya)

S.2 : Nyuwun sewu ustadz tak hapuskan dulu

(permisi ustadz saya hapuskan dulu)

(konteks: berdiri dan menghapus papan tulis)

Penggalan tuturan dalam interaksi antara ustadz dengan santri ditemukannya ilokusi direktif pada penutur (U) pada kalimat duh papane ruesik $e$ maksud dari kalimat tersebut adalah untuk memberi kode kepada santrinya agar membersihkan papan tulis yang kotor supaya bisa 
menerangkan materi yang diajarkan. Kalimat tersebut menjadi penerapan tindak berbahasa karena cara penyampaiannya penutur $U$ kepada lawan penuturnya, bisa dilihat kalimat berikut.
a. Anak-anak tolong bersihkan papan tulisnya terlebih dahulu
b. Tolong bersihkan papan tulisnya
c. Duh.. papan tulisnya sangat bersih ya

Tingkatan formal kalimat (a) lebih besar dari pada kalimat (b); serta kalimat (b) lebih besar dari pada kalimat (c). Jadi, kalimat (c) lebih kecil dalam keformalan kalimat, serta yang dimaksud penutur sudah dipahami oleh lawan penutur. Terjadinya ilokusi direktif karena penutur meminta lawan penutur untuk menghapus papan tulis.

Selanjutnya pada tindak berbahasa lainnya terletak pada penerapan interaksi antara santri dengan pengurus keamanan, dengan pembahasan tuuran mengenai ketika santri meminta izin untuk pulang ke rumah pada pengurus keamanan, tapi pengurus keamanan membujuk santri agara tidak pulang ke rumah. Sebagaimana penggalan tuturan para santri sebagai berikut.

Kutipan 2 kode IBRPASDP

P1 : "Oalah yo... yo... kok ndadak men.. kangen toh ya bisa vcan, anakanak semua yo di sini ndak pulang. Apalagi besok ada lengseran"

(oalah.. kok dadakan banget.. kangen kan ya bisa vcan, anakanak semjua ya di sini gak pulang. Apalagi besok ada lengseran (makan besar bersama))

(konteks: membujuk santri dengan memberitahu besok ada acara)

S1 : "hehe.. ada acara apa kang kok lengseran?"

(ada acara apa kak kok lengseran?)

(konteks: penasaran dengan pernyataan pengurus keamanan)
Kutipan tuturan dalam tindak berbahasa antara santri dengan pengurus keamanan ditemukannya ilokusi direktif pada penutur P1 pada kalimat oalah yo.. yo... kok ndadak men.. kangen toh ya bisa vcan, anak-anak semua yo di sini ndak pulang. Apalagi besok ada lengseran maksud dari kalimat tersebut adalah membujuk santri agar tidak balik ke rumah dan menetap di pesantren dengan cara memberi tahu bahwa ada acara lengseran di pondok pesantren. Adanya ilokusi direktif karena penutur (P1) meminta lawan penutur (S1) untuk tidak pulang ke rumah.

\section{Ilokusi Ekspresif}

Tindak berbahasa para santri di pondok pesantren Nurul Ilmi Wal Fikri Jombang ini mengandung ilokusi ekspresif. Terjadinya ilokusi ekspresif ini karena timbul suatu ekspresi atau ungkapan perasaan melalui tuturan dan menimbulkan tujuan komunikasi dan penerapan komunikasi melalui sebuah tindakan. Tempat kejadian yang terjadi fenomena ilokusi ekspresif terdapat pada tempat aula pengajian dan kamar mandi. Kejadian tersebut dilakukan agar terpenuhinya data yang dibutuhkan dalam penelitian.

Seperti pada saat di aula pengajian terdapat beberapa santri saling berinteraksi membahas tentang tugas materi yang diberikan oleh ustadz mereka. Sebagaimana kutipan tuturan berikut ini.

Kutipan 3 kode IBA3SDU

S.2 : "Eh kie, btw wis pada apal nadhomane apa urung?"

(eh ngomong-ngomong, udah ada yang hafal belum nadhomannya?)

(konteks: bertanya kepada teman sejawatnya tentang pembelajaran yang akan datang)

S.3: "Dereng eh, nadhomane niku sisah" (belum juga, nadhomannya itu susah)

(konteks: menjawab dengan ekspresi kesulitan) 
Kutipan di atas dalam tindak berbahasa para santri ditemukannya ilokusi ekspresif pada tuturan dereng eh, nadhomane (lirik atau syair dalam sebuah kitab) niku sisah dari tuturan tersebut terdapat ungkapan perasaan bahwa dari lawan penutur (S.2) yang menanyakan tentang materi hafalan kepada penutur(S.3). Ungkapan perasaan pada kutipan di atas memberi tahu kepada lawan penutur bahwa penutur masih bingung dan belum bisa pada materi yang dimaksud, sehingga dari tuturan tersebut lawan penutur juga memahami apa yang dimaksud penutur.

Selain itu, terdapat juga kutipan para santri yang mengandung fenomena ilokusi ekspresif seperti pada saat di kamar mandi, ketika salah satu santri menyuruh temannya untuk cepat keluar dari toilet. Sebagaimana kutipan berikut.

Kutipan 4 kode IBKSASDP

S.1 : "Ayo rek ojok sue sue, selak ro'an" (ayo jangan lama-lama nanti keburu ro'an)

(konteks: mengetok pintu sambil bernada keras)

S.3 : "Iyo sek sabar (buka pintu) oalaah.. sabar toh ping ping.. gupuhi wong ae"

(iya sebentar (buka pintu) oalah.. sabar dong ping ping.. buru-buruin orang aja)

(konteks: memandang temannya dengan nada agak kesal)

S.1 : "Selak ro'an polae yowes minggiro" (karena nanti keburu ro'an ya sudah minggir)

(Konteks: sambil masuk ke kamar mandi)

Kutipan di atas dalam tindak berbahasa para santri ditemukannya ilokusi ekspresif terdapat pada dua tuturan; pertama, iyo sek sabar oalaaah.. sabar toh ping ping. gupuhi wong ae. Serta pada tuturan kedua, selak roan polae yowes minggiro. Dikatakan adanya ilokusi ekspresif karena dua tuturan tersebut mengandung unsur perasaan yang memiliki tujuan tertentu serta berkembangnya dan penerapan pada interaksi para santri tersebut.

Ungkapan perasaan pada tuturan pertama yakni dengan pembawaan agak kesal dan memberi respon kepada lawan penutur untuk lebih bersabar pada saat antri dalam giliran ke toilet. Sedangkan tuturan kedua ungkapan perasaan yang dimiliki penutur agak jengkel kepada lawan penuturnya tetapi jengkelnya disebabkan karena adanya suatu kondisi atau keadaan tertentu.

\section{Ilokusi Komisif}

Tindak berbahasa para santri di pondok pesantren Nurul Ilmi Wal Fikri Jombang ini mengandung fenomena ilokusi komisif. Terjadinya fenomena ilokusi komisif ini karena adanya sifat menjanjikan dan menawarkan atau untuk menolak suatu tindakan melalui tuturan dan menimbulkan tujuan komunikasi dan dikembangkan melalui sebuah tindakan. Interaksi yang mengandung fenomena ilokusi komisif terdapat pada tempat aula pengajian dan ruang pengurus, hal tersebut dilakukan agar terpenuhinya data yang dibutuhkan dalam penelitian.

Seperti pada interaksi antar santri di tempat aula pengajian ketika para santri membuat kesepakatan untuk materi yang akan dipelajari bersama ustadz mereka. Sebagaimana kutipan berikut ini.

Kutipan 5 kode IBA3SDU

S.2 : "Ngkok kayak kie bae wis, ngomong karo ustadz lukman sorogan bae karo ngulang materi seng wingi, nyong patia hapal soale"

(nanti seperti ini saja, katakan sama ustadz lukman pembelajaran nanti ini sorogan saja)

(konteks: menatap para teman sejawatnya dengan memberikan sebuah usulan)

S.3 : "Kulo manaut mawon pripun sae $n e$ "

(saya ikut saja bagaimana baiknya)

(konteks: mengikuti apa kata sepakatan para temannya)

S.1 : "Tontok ngkok ae lah gampang" 
(lihat nanti saja lah gampang)

(konteks: melihat situasi atau keadaan yang akan datang)

Adanya fenomena ilokusi komisif pada kutipan di atas dalam interaksi para santri terdapat dua tuturan; pertama, ngkok kayak kie bae wis, ngomong karo ustadz lukman soroga (sistem belajar mengajar dengan murid membaca guru menyimak) bae karo ngulang materi seng wingi. Kedua, tontok ngkok ae lah gampang. Dikatakan adanya komisif karena dua tuturan tersebut mengandung unsur penawaran dan menolak suatu tindakan yang memiliki tujuan tertentu serta berkembangnya pada interaksi para santri tersebut.

Tuturan pertama yang menyebabkan adanya ilokusi komisif karena ada unsur penawaran, objeknya kepada para teman sesama santrinya untuk materi yang akan dipelajari. Sedangkan tuturan kedua disebabkan adanya ilokusi komisif karena ada unsur menolak suatu tindakan atau si penutur ini tidak setuju dengan tawaran lawan penuturnya dengan membuat respon seperti itu, yang mengakibatkan adanya berkembangnya sebuah tuturan dari sang penutur.

Selanjutnya bentuk ilokusi komisif lainnya pula tampak ketika seorang santri berinteraksi dengan pengurus keamanan dengan tujuan meminta izin pulang ke rumah namun pengurus keamanan mencoba memberikan pilihan kepada santri agar tidak pulang. Sebagaimana interaksi berikut.

Kutipan 6 kode IBRPASDP

P1 : "Tapi ya terserah kamu, kalau pengen banget pulang saya kasih surat izinnya trus soan ke kyai buat minta ttd ke beliaunya sambil pamitan"

(konteks: memberi piilihan kepada santri)

S1: "Iya kang gak papa, udah kangen pol polae"

(iya kak tidak apa-apa, karena sudah kangen banget)

(konteks: memilih pulang dengan ekspresi gembira)
Penggalan tuturan dalam interaksi antara santri dengan pengurus keamanan ditemukannya ilokusi komisif pada penutur P1 pada kalimat tapi terserah kamu, kalau pengen banget pulang saya kasih surat izinnya trus soan (berkunjung/menghadap) ke kyai buat minta ttd ke beliaunya sambil pamitan. Karena dari tuturan tersebut adanya bentuk penawaran dari pengurus keamanan kepada santrinya ketika meminta izin untuk pulang ke rumah agar tetap di pondok, maka dari itu menyebabkan adanya fenomena ilokusi komisif.

\section{PENUTUP}

Berdasarkan hasil analisis tuturan ilokusi dalam interaksi bahasa para santri di pondok pesantren Nurul Ilmi Wal Fikri Jombang, dapat disimpulkan bahwa setiap berinteraksi tentu akan adanya tindak lanjut atau penerapan dan tujuan bisa berupa lisan ataupun tingkah laku. Pada penelitian ini, menggunakan fenomena ilokusi yang terdapat tiga bagian yakni; ilokusi direktif, ilokusi ekspresif, dan ilokusi komisif. Adanya Ilokusi direktif pada saat penutur memengaruhi lawan penutur untuk melakukan suatu tindakan tertentu. Sedangkan ilokusi ekspresif terdapat pada saat lawan penutur memberikan respon ekspresi atau perasaan dari ucapan sang penutur. Untuk ilokusi komisif sendiri terdapat pada saat penutur memberikan sebuah penawaran atau untuk menolak suatu tindakan.

\section{REFERENSI}

Haris. 2017. Tindak Tutur Berbahasa Gorontalo Masyarakat Desa Pelambane Kecamatan Randangan [Skripsi]. Gorontalo (ID): Universitas Negeri Gorontalo.

Ibrahim, Abd Syukur. 2016. Kajian Tindak Tutur. Surabaya: Usaha Nasional.

Ibrahim, Abd Syukur. 2016. Panduan Penelitian Etnografi Komunikasi. Surabaya: Usaha Nasional.

Intan. 2019. Bentuk Dan Jenis Tindak Tutur Ilokusi dalam Novel Prancis perfume karya Patrick Suskind Terjemahan Indonesia 
[Skripsi]. Sumedang (ID): Universitas Padjajaran.

Lina. 2016. Fungsi Basa Basi Dalam Tindak berbahasa di kalangan Masyarakat Jawa [Skripsi]. Surakarta (ID): Universitas Muhammadiyah Surakarta.

Mubarok, Muhammad Farid. 2019. Tindak Tutur Kesantunan Berbahasa di Lingkup MTS Negeri 05 Jombang [Skripsi]. Jombang (ID): Universitas Hasyim Asy'ari

Rahardi Kunjana. 2016. Sosiopragmatik. Jakarta: Penerbit Erlangga 